\title{
Conceptual Issues in the Qualification of Intelligent Buildings
}

\author{
Ogwu Ikechukwu ${ }^{*}$, Okonkwo Moses ${ }^{2}$ \\ ${ }^{1}$ College of Civil Engineering and Mechanics, Xiangtan University, Xiangtan, China \\ ${ }^{2}$ Faculty of Environmental Science, Nnamdi Azikiwe University, Awka, Nigeria \\ Email: *ogwu@smail.xtu.edu.cn
}

How to cite this paper: Ikechukwu, O. and Moses, O. (2019) Conceptual Issues in the Qualification of Intelligent Buildings. Open Journal of Energy Efficiency, 8, 52-63. https://doi.org/10.4236/ojee.2019.82004

Received: May 8, 2019

Accepted: June 11, 2019

Published: June 14, 2019

Copyright (C) 2019 by author(s) and Scientific Research Publishing Inc. This work is licensed under the Creative Commons Attribution International License (CC BY 4.0).

http://creativecommons.org/licenses/by/4.0/

\begin{abstract}
The reality of global warming must have been settled by now while the incidence of same has in very recent times adopted unprecedented dimensions. The global community continues to look for ways to combat the impact of climate change and technology is looked upon to deliver the innovations that would ensure a better tomorrow today. Rapid advancement of Information Technology (IT), is now transforming the way we create and interact with the built environment with the notion of Intelligent Buildings (IBs) underscoring its main features. However, these IBs utilize systems that require energy, and fossil fuels are currently the world's primary energy sources; they can also irreparably harm the environment, exacerbating climate change. What then is the true essence of IBs? This paper, through review of existing literature, attempts to explore some issues associated with the conceptualization of IBs, highlighting how they are similar with other notional options that deliver the same benefits but without the needed IT systems or the energy required in running them. It also discusses the need to focus on less energy demanding and management approaches at design or occupancy of buildings as a way to reduce the demand and thus consumption of fossil fuels across the world.
\end{abstract}

\section{Keywords}

Technology, Climate Change, Energy, Energy Efficiency, Building Energy

Assessment, HVAC, Façade Systems, Passive Design, Smart Materials, Intelligent Buildings

\section{Background}

As world population continues to increase, urban areas are projected to house $60 \%$ of people globally, and one in every three people will live in cities with at 
least half a million inhabitants [1]. This will "...add to the growing demand for housing, water supply, sanitation and other urban services" [2], requiring the erection of taller and taller buildings, enclosing larger and larger spaces [3]. Already, buildings are some of the biggest energy consumers in the world, accounting for one-quarter to one-third of all energy use and a similar amount of greenhouse gas emissions. In China alone, energy consumption by buildings has risen from $10 \%$ in the late 1970 's to more than $25 \%$ in 2006 , and is expected to soar to $35 \%$ soon [4]. Buildings consume energy at different levels in every stage of their life-cycle and building materials occupy a great share of this consumption [5].

Over the past few decades, the construction sector has been under increasing pressure to improve its cost efficiency, sustainability, and capacity, pushed by the endeavor and need to face consequences of global warming and climate change. Indeed, the increased awareness of climate change and other environmental concerns are empowering innovative solutions that seek to improve the quality of life while being environmentally-friendly [6]. It is believed that science and technology at their best are motivated to satisfy genuine human needs that the needs of the city will be satisfied, and technology, spurred by the discoveries and inventions of the industrial and scientific revolutions, has come to help [3]. However, practically all technologies require energy, and fossil fuels are still a major part of the world's energy mix. In fact, energy, which is linked with all aspects of development and has a tremendous impact on the well being of urban citizens health, education, productivity, as well as economic opportunities, is primarily sourced from coal, oil and gas (fossil) [7]. Review of literature reveals that about $68 \%$ of global energy is generated from the combustion of fossil fuels, with coal accounting for more than $40 \%$ of total production. Although on the one hand, the share of oil in power production has decreased considerably from $23 \%$ to $6 \%$ since the first oil crisis in 1973 , on the other hand, the share of natural gas has increased from $12 \%$ to $21 \%$ [8]. Renewable energy sources contribute only about $18 \%$, with hydropower accounting for more than $85 \%$ of this [8]. Also, in recent times, China, the world's second biggest economy, has been transformed from an energy exporter (as recently as the early 1990's) to the world's third-largest net importer of oil in 2006. The growth rate of its energy consumption through 2030 is predicted to be the highest in the world. With nearly half of the world's new building construction in China, energy demand by buildings is projected to also increase [4].

\section{Push towards Energy Efficiency}

With the development of the world economy, the situation of energy crisis and environmental impact is serious [9]. The high energy consumption in buildings and climate change due to global warming are now big challenges to development. According to new research by construction blog Bimhow, the construction sector contributes up to $23 \%$ of air pollution, $50 \%$ of the climatic change, 
$40 \%$ of drinking water pollution, and $50 \%$ of landfill wastes. In separate research by the US Green Building Council (USGBC), the construction industry accounts for $40 \%$ of worldwide energy usage, with estimations that by 2030 emissions from commercial buildings will grow by $1.8 \%$ [10]. One reason (for the high energy consumption by buildings) is that throughout the 20th century, a large percentage of buildings were constructed (to be) completely dependent on fossil fuels. Rather than focusing on energy efficiency, architects and engineers were more concerned with furthering only their aesthetic ideals [11]. Indeed, the way buildings are designed, constructed, serviced and how they are adapted over time, all directly influence the volume of fossil fuels consumed and lead directly to the tonnes of carbon dioxide released into the atmosphere, raising planetary temperatures [12]. Consequently, if buildings are responsible for almost half of total energy use globally, then, the urban built environment with its complex matrix of buildings, activities, services and transportation consumes $75 \%$ of the world's energy resources and produces the vast bulk of its pollution and climate change gases [12]. This indicates therefore that action to develop buildings that are energy efficient will go a long way in reducing the volume of fossil fuel demanded and consumed by buildings, from construction to occupancy. In line with this, energy efficiency and conservation have now taken on a new importance. As the global community struggles with satisfying new energy demand with less-carbon intensive approaches, it is agreed that efficiency provides the fastest and least expensive way to meet energy needs [13]. Indeed, consumption of fossil fuels can be reduced through efficiency [14]; it is the easiest, quickest, and least expensive way to fight global warming. In China, the national energy policy is now gradually shifting from a previous focus solely on energy development to emphasis on both development and efficiency; building and transport sectors are now being accorded the same importance in the energy conservation policy as the industrial sector [4].

\section{Some Approaches towards Energy Efficiency in Buildings}

Although there are many approaches towards achieving energy efficiency in buildings, this paper only highlights some of them in an attempt towards establishing their advantages in reducing or possibly eliminating the energy demands of buildings, and also without the added control or monitoring of energy demanding computer information technology systems upon which IBs (as discussed later) are based.

\subsection{Building Environmental Assessment (BEA) Methods}

Numerous attempts have been made to reduce the environmental impact of construction. Many cases for energy efficient buildings have been developed across the world and new strict codes issued for enforcement [6]. Review of literature reveals that building energy codes and standards (will) provide the basic requirements for energy-efficient design and construction for new and reno- 
vated buildings, ensuring reductions in energy use and greenhouse gas emissions over the life of buildings [15]. It is argued that the adoption of model codes will present a significant opportunity to save energy in residential and commercial buildings. The ISO focus also reports that standards can help improve energy efficiency and enhance energy management, asserting that their ISO 50001 standard is one of many that can help ensure access to affordable, reliable and modern energy for all by 2030 and reduce carbon emissions, limiting the rise in earth's temperature to below $2^{\circ} \mathrm{C}[16]$.

At the same time, many research institutes have also developed Building Environmental Assessment (BEA) methods, where energy efficiency is an important factor. Further research reveals that the development of BEA tools is motivated by increased public awareness of environmental issues, highlighting the need for both building constructors and owners to estimate environmental impacts; the aim being to improve the environmental performance of buildings by focusing on energy consumption, heat insulation, air quality, light, noise, land use, material consumption, water efficiency, etc. [17]. They also reveal that beyond these range of factors (from energy, water and land use, to safety and design), BEA also summarizes their impact as an aggregate indicator by weighting each factor. BEA aims to comprehend these wide coverage for better design and action that is environmentally friendly. BEA offers guidelines to secure sustainability not only for inhabitants but also for future generations. Indeed BEA has been instituted to combine all the different complicated issues into a single principle with simple but diverse grading structure to assess environmental impact.

\subsection{Heating, Ventilation and Air-Conditioning (HVAC) Control, and Passive Design}

It is commonly believed that maintaining constant or fixed indoor environmental conditions ensures comfort and satisfaction. Consequently, in order to ensure productivity of occupants, indoor temperature is usually maintained at a fixed value that will dissatisfy the least number of people. However, keeping the indoor temperature at a constant or fixed value is energy intensive, with huge implications both for resource consumption and environmental impact. The HVAC (heating, ventilation and air-conditioning) systems, (especially in tall office buildings), account for $33 \%$ or more of overall building energy consumption. Therefore, the increased efficiency, or possibly elimination-of these systems could be the most important single step in making (tall) buildings more sustainable, reducing their energy demand [18]. Also, studies now reveal that as many as $43 \%$ of occupants are actually dissatisfied with HVAC, and $56 \%$ to $89 \%$ of government workers regard HVAC as a problem in Europe and the US [19]. Field studies actually reveal that people accept a larger range of temperature variation in naturally ventilated buildings than in air-conditioned ones. In China, a study was conducted to rate user satisfaction with household air conditioning; it revealed that over $50 \%$ of surveyed families were currently dissatisfied 
[20].

In addition, since heating, cooling, and lighting are accomplished by adding energy to or removing it from a building, and since the consumption of energy is causing global warming, some argue that architects can produce low energy demanding sustainable buildings especially from the decision making design stage so that important options are considered at the appropriate time. The cost of a building and its impact on the environment can be ascertained at the preliminary design/sketch stage by decisions on form, orientation and size; these three factors ultimately determine how much energy and resources will be needed or consumed during construction and occupancy. Thus, sustainability in buildings can be achieved by decisions made early in the design process as against supplementary engineering actions made post design or during construction [14]. Others believe that buildings with properly designed spaces can breathe naturally without the use of mechanical systems; they suggest that true natural ventilation can be achieved by considering the building's structure, envelope, energy use, and form, thereby giving the occupants thermal comfort and healthy indoor air [21].

\subsection{Façade Systems}

Alternative façade systems - the double skin façade system generally addresses the practical need for improved indoor environment and ensures the reduction of energy use during the occupation stage of a building providing both improved indoor conditions and reduced use of energy at the same time [22]. Double façades provide an effective means of buffering and controlling heat, light, air and noise through a building. The principle involves an additional layer of wall offset from the conventional one forming an interstitial space that acts as a thermal buffer. In some instances, blinds could be incorporated into the space to prevent solar heat gains. These blinds could be manually operated, further reducing energy requirements [23]. Reference [24] explains the Double Skin Façade system as essentially a pair of glass "skins" separated by an air corridor. The primary surface usually glass, is protected, and the air space acts as a safeguard against extreme temperatures, wind as well as sound. Sun-shading devices are often located between the two skins. A double skin façade is much like a second cover wall fixed right over the original perimeter wall. This additional façade is mainly transparent. The resulting area between the two skins is a space that helps to minimize heat gains in the building. This space could also be oriented to receive solar radiation during cold seasons [25]. It has also been described as an active façade covering one or several storey's constructed with multiple glazed skins which can be air tight or not, the air cavity between the skins naturally or mechanically ventilated [26]. One of the main advantages of the Double Skin Façade systems is that they can allow natural (or fan supported) ventilation when possible [22]. Indeed, they can have major benefits for temperature, air flow, as well as on the air quality which gets inside the building; and if properly designed, this natural ventilation can result in a significant drop in 
energy use during occupancy as well as improve occupant comfort.

\subsection{Smart Materials}

Described as exceptionally structured substances which manifest quick responses to their surroundings, smart materials have intrinsic or implanted intelligence abilities. Smart refers to notions of alertness and well informed responses as well as attributes of vigilance and swiftness. According to NASA these smart materials can recall the arrangement of elements in a particular form and then (re)adjust to them under specific conditions. The Encyclopedia of Chemical Technology describes them as items or objects that perceive surrounding events, analyze them and then deploy suitable responses [27]. Smart materials have been shown to be responsive to external stimulus in order to control temperature changes or solar radiation as can be seen in electro-chromic glass with glazing material in curtain walls, windows, shading devices and other applications [28]; they have also been applied in smart solar skins, building facades and shape morphing solar shadings, all saving energy costs in the short and long terms [29].

\section{Qualifications of Intelligent Buildings}

The concept of Intelligent Buildings is not new. The term has been in use since the early 1980s, with the first definition given by the Intelligent Buildings Institute as "one which provides a productive and cost-effective environment through optimization of four basic elements: structure, systems, services and management, and the interrelationship between them" [30]. Intelligent buildings use technology to provide a more efficient environment by enhancing the connection between a buildings form, flow, mechanical and electrical services as well as its operation [31]. These definitions present intelligent buildings as one which adjusts its basic elements to meet user requirements using technology to make the communication between the elements possible. Indeed, intelligent buildings feature the surveillance of all service and communications functions, as well as safety/security, environmental control and electricity management as an integrated system, and provides responsive measures in an attempt to mitigate losses, optimize energy use and guarantee occupant comfort (see Figure 1).

These feature of intelligent buildings are computer based involving sensors that can detect changes in the environment, relay mechanisms that communicate the changes detected to a central system which then deploys counter mechanisms. They can come as add-ons to an existing building or can be considered from the design stage. Intelligent buildings have also been described as one in which the building fabric, space, services and information systems can respond in an efficient manner to the initial and changing demands of the owner, the occupier and the environment [32].

Historically, one of the first uses of the term "smart" (in association with intelligent buildings) was in connection with improved sensor-based monitoring 


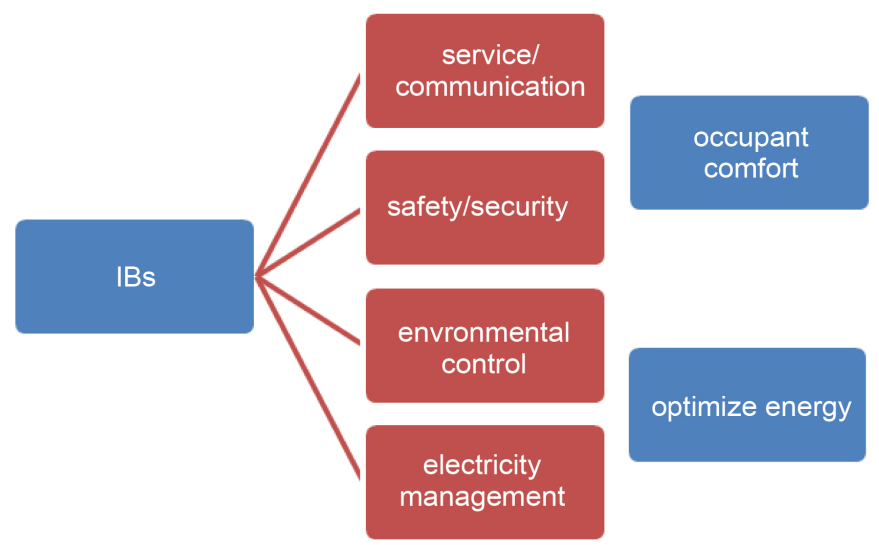

Figure 1. Basic concept of Intelligent Buildings (IBs).

and control systems for regulating the thermal environment in a building (the "Smart House" of the 1990s) in a Washington Post article [27]. The article describes this "smart house" as being "imbued with computer intelligence... needing an extra six miles of wiring... and walls that conceal a household-wide skeleton of pipes to facilitate the distribution of data throughout the house" [33]. Indeed, this make it clear that in order to fully optimize the performance of intelligent buildings, smart materials are fully connected to computer control systems.

Studies reveal that in 1975, the US state of California began implementing strict energy efficiency standards for buildings and home appliances as part of its solution to air pollution, and by 1984, the City Place Building in Hartford, Connecticut was completed. This 38-story office building, hailed as the world's first intelligent building, was however equipped with advanced telecommunications, office automation, automatic monitoring, and architecture equipment management systems, with a thinking "brain" of sorts, implanted in the building, which marked the advent of the intelligent building sector [34].

Now given that the world's electricity production is still mostly coal-fired, any increase in energy consumption in buildings will turn out to be a source of air pollution as well. In a push to create more intelligent buildings, well-functioning intelligent advanced equipment and data management support and expert capacity are needed, which ultimately lead to increased costs and increased electricity demand (see Figure 2).

Various sensors are needed on the surface of, and inside an intelligent building to transmit real-time data including temperature, sunlight intensity and levels of air pollution, as well as the energy consumption so that they can be re-aligned with more favorable conditions. Also, there must be an expert team to research and compare operation data, in order to create an optimal solution to balance energy consumption and comfort. In terms of operating costs, a balance must be struck between the focus on a particular function and the emphasis on overall energy efficiency. For example further review of existing literature revealed that the pure pursuit of high indoor air-purification capacity will consume 


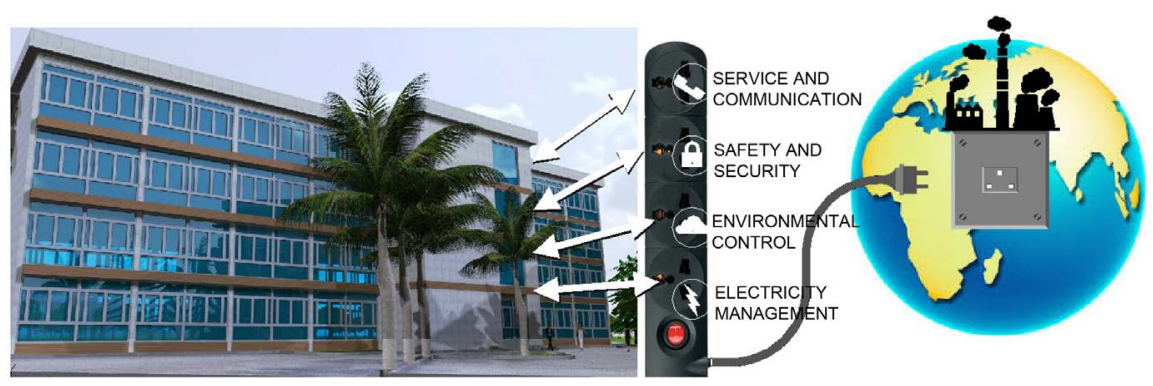

Figure 2. Features of Intelligent Buildings powered by energy primarily from the combustion of fossil fuels.

more energy and cause higher pollution at large [34]. With the afore mentioned why does the notion of intelligent buildings still remain attractive today? Some argue it is because intelligent buildings feature an Intelligent Building Management System (IBMS) which provide integrated management features similar to a buildings brain-monitoring, interacting and management for all the buildings other automation systems at real time, including access control, audio/video intercom, wireless networking infrastructure, structure cabling system, CCTV/DVR surveillance system, computer room facilities, electrical distribution, lighting control and information display system, etc, making overall management of the building easier [35]. Also, there are studies which reveal that installing technology to meter and monitor energy consumption has an average payback period of less than 6 months; thus, a small increase in capital expenditure, they believe, can reduce operational expenditure significantly. Indeed empirical studies of metering solutions show an average of $5 \%$ reduction in utility bills in different buildings [36]. A state of the art Intelligent Building employs many integrated mechanical and electrical systems that control the buildings environment, lighting and security to maintain high-speed data networks and emergency backup power generators. Incorporating these systems into the building, saves energy while increasing reliability, security and efficiency, making the building more desirable for prospective occupants. However, it is all so critical that these systems function continually and reliably. If faults develop and they are not detected and repaired quickly, malfunctioning mechanical and electrical systems in an Intelligent Building can pose serious consequences putting the lives of occupants at risk, unreliable network connections can also impair the proper functioning of the building hampering workers productivity. Indeed there has to be a serious commitment to maintaining an Intelligent Building which can only be ensured by constant power.

It has also been posited that the Intelligent Building concept is becoming mainstream because of its capacity for utilizing creative initiatives and modern information technology with sustainable design as an approach to ensure the comfort of building occupants. These days, Intelligent Buildings have a certain appeal because they are enabling the connectivity between people and their environment, allowing the building to become much more real and effective. From 
the economic point of view however, it is also essential to debate the initial high costs and reliability of the implementation of these intelligent technologies, such as sensors and actuators that are still new and have not gained wide spread acceptance. There are also the related issues of running, maintenance and energy costs, the innovation for even newer products to aid real time feedback, self-healing and low embodied materials (for energy efficiency), biomimetics (for economical use of materials and energy), robotics (for maintenance and internal surveys), using chaos, and complex theory and network science, all of which makes them (Intelligent Buildings) highly unaffordable [37]. Additionally, there is also the general shortage of expertise for monitoring their operations especially for residential buildings, not to mention the possibility of hacking them. It is suggested therefore that IBs should rather respond to smartness and technology awareness, economic and cost efficiency, personal and social sensitivity, as well as environmental responsiveness [ibid].

\section{Conclusions}

Although intelligent buildings present an attempt to save energy and optimize building performance, in the long run, the systems upon which they operate make the concept nugatory. Sensors, receptors, computer based monitoring and control systems are the core of intelligent buildings and these installed systems have to be maintained and kept running with energy which is currently mainly sourced from the consumption of fossil fuels-coal or oil and gas. Buildings are already the largest consumers of the existing supply of the world's energy, focus should be on how to reduce this through best practices, and not to increase its demand. An approach would be to consider total energy independence from the existing major source (fossil fuels) in the form of renewables. However, renewable energy systems still fall short because of their high upfront cost, intermittency, and general low capacity. There are also the associated environmental impacts such as resulting water shortages in surrounding areas where a river would have flown to in the case of dams built to harness hydropower, the nitrogen trifluoride greenhouse gas attributed to be over 17,000 times more harmful than carbon dioxide used in the manufacture of certain types of photovoltaic cells for solar panels, and so on. Consequently, until the global community finds more considerable alternatives, focus and attention should indeed be on energy efficiency and zero energy demand technologies for buildings: smart materials as sensors could be made to respond naturally to environmental stimuli without controlled computer intelligence such as by changing color in response to light intensity or heat (photo-chromic or thermo-chromic) which can be used in glass windows; sustainable architecture achieved by combining the best of the old and the new, resulting in an architecture that passively responds to human needs, regionalism, and climate.

Indeed, opportunities abound for energy efficiency in buildings but focus should be on approaches that reduce or manage the existing supply of energy 
both in the short and long terms.

\section{Acknowledgements}

Ogwu Ikechukwu thanks Prof. Zhilin Long under whose supervision the work was carried out, and Prof. Rongguo Zhao, for his review of the first manuscript. Both Professors are of the College of Civil Engineering and Mechanics, Xiangtan University, Hunan, China.

\section{Conflicts of Interest}

The authors declare no conflicts of interest regarding the publication of this paper.

\section{References}

[1] UN Data Booklet-ST/ESA/SER.A/392 (2016) The World's Cities in 2016.

[2] UN-HABITAT-GRHS/05/F2 (2005) The Housing Crisis. United Nations Human Settlements Programme.

[3] Salvadori, M. (1980) Why Buildings Stand up-The Strength of Architecture. W. W. Norton and Company, New York and London.

[4] Hong, W., Chiang, M.S., Shapiro, A.R., Clifford, M.L. and Laurenzi, P.M. (2007) Building Energy Efficiency: Why Green Buildings Are Key to Asia’s Future. Asia Business Council, Hong Kong.

[5] Yuksek, I. (2014) The Evaluation of Building Materials in Terms of Energy Efficiency. Periodica Polytechnica Civil Engineering, Creative Commons Attribution.

[6] Ogwu, I. and Nzewi, N.U. (2017) Adopting the Principles of Building Physics, Smart Materials and New Technologies in the Design of Energy Efficient Buildings. Environmental Review, 6, 1-13. http://erjournal.net/index.php/erjournal/article/view/30/pdf1

[7] Ghiaus, C. and Inard, C. (2019) Energy and Environmental Issues of Smart Buildings.

http://citeseerx.ist.psu.edu/viewdoc/download?doi=10.1.1.582.2152\&rep=rep1\&type $=\mathrm{pdf}$

[8] Grubler, A., Nakicenovic, N., Pachauri, S., Rogner, H.-H., Smith, K.R., et al. (2014) Energy Primer. International Institute for Applied Systems Analysis, Laxenburg.

[9] Gu, Z. (2007) Approaches to Energy Efficient Building Development-Studying under Chinese Contexts. Royal Institute of Technology, School of Industrial Engineering and Management, Division of Industrial Ecology, Stockholm.

[10] Snook, J. (2017) How Does Construction Impact the Environment? https://www.initiafy.com/blog/how-does-construction-impact-the-environment

[11] Michelle, A. and Daniel, S. (2005) Smart Materials and New Technologies: For the Architecture and Design Professions. Architectural Press, Boston.

[12] Okonkwo, M.M. (2007) The National Building Code and Sustainability of Built Environment Development in Nigeria. 3-Day National Conferencel Training Workshop on "The National Building Code and the Future of the Nigerian Built Environment", September 27-29 2007.

[13] Keogh, M. and Rowlett, J. (2009) Eight Approaches to Enable Greater Energy Efficiency: A Guide for State Government Officials. 
https://www.epa.gov/sites/production/files/signpost/cc.html

[14] Nobert, L. (2015) Heating, Cooling, Lighting: Sustainable Design Methods for Architects. John Wiley and Sons, Hoboken.

[15] Livingston, O.V., Cole, P.C., Elliott, D.B. and Bartlett, R. (2014) Building Energy Codes Program: National Benefits Assessment, 1992-2040. Prepared for the U.S. Department of Energy under Contract DE-AC05-76RL01830. Pacific Northwest National Laboratory Richland, Washington DC.

[16] ISO Focus (2016) The Rise of Energy Efficiency. Issue No. 119.

[17] Kajikawa, Y., Inoue, T. and Goh, T.N. (2011) Analysis of Building Environment Assessment Frameworks and Their Implications for Sustainability Indicators. Integrated Research System for Sustainability Science, United Nations University, Tokyo and Springer, Berlin. https://doi.org/10.1007/s11625-011-0131-7

[18] Wood, A. and Salib, R. (2013) Natural Ventilation in High-Rise Office Buildings (an Output of the CTBUH (Council on Tall Buildings and Urban Habitat). Sustainability Working Group, Illinois Institute of Technology, Routledge, New York.

[19] Allard, F. and Ghiaus, C. (2006) Natural Ventilation in the Urban Environment. In: Santamouris, M. and Wouters, P., Eds., Building Ventilation: State of the Art, Routledge, London, 38.

[20] Long, W., Zhong, T. and Zhang, B. (2019) China: The Issue with Residential Air Conditioning. Department of Facilities Engineering and Management, Tongji University, Shanghai.

[21] Passe, U. and Battaglia, F. (2015) Designing Spaces for Natural Ventilation-An Architect's Guide. Routledge Taylor and Francis Group, New York and London.

[22] Poirazis, H. (2004) Double Skin Façades for Office Buildings. Division of Energy and Building Design, Department of Construction and Architecture, Lund Institute of Technology, Lund University, Lund, Report EBD-R-04/3.

[23] Stribling, D. and Stigge, B. (2002) A Critical Review of the Energy Savings and Cost Payback Issues of Double Facades.

[24] Harrison, K. and Meyer-Boake, T. (2003) The Tectonics of the Environmental Skin. University of Waterloo, School of Architecture, Waterloo. http://www.fes.uwaterloo.ca/architecture/faculty_projects/terri/ds/double.pdf

[25] Claessens, J. and DeHerde (2010) Active Solar Heating and Photovoltaic's. Solar Energy in European Office Buildings. Energy Research Group, School of Architecture, University College of Dublin, Dublin.

[26] Belgian Building Research Institute (BBRI) (2002) Source Book for a Better Understanding of Conceptual and Operational Aspects of Active Facades. Department of Building Physics, Indoor Climate and Building Services, Belgian Building Research Institute, Version No. 1. http://www.bbri.be/activefacades/index2.htm

[27] Addington, M. and Schodek, D. (2005) Smart Materials and New Technologies: For the Architecture and Design Professions. Architectural Press, Boston.

[28] Saidam, M.W., Al-Obaidi, K.M., Hussein, H. and Ismail, M.A. (2017) The Application of Smart Materials in Building Facades. Ecology, Environment and Conservation, 23, 8-11.

[29] Fiorito, F., Sauchelli, M., Arroyo, D., Pesenti, M., Imperadori, M., Masera, G. and Ranzi, G. (2016) Shape Morphing Solar Shadings: A Review. Renewable and Sustainable Energy Reviews, 55, 863-884. https://doi.org/10.1016/j.rser.2015.10.086 https://www.sciencedirect.com/science/article/pii/S136403211501165X?via\%3Dihub

[30] Peluffo, M. (2015) Defining Today’s Intelligent Building. Commscope. 
https://www.commscope.com/Blog/Defining-Todays-Intelligent-Building

[31] Caffrey, R. (1985) The Intelligent Building-An ASHRAE Opportunity. ASHRAE Technical Data Bulletin, 4.

[32] ARUP (2015) Building Physics. http://www.arup.com https://zh.scribd.com/document/266342560/AED-building-physics-pdf

[33] Lehman, J.H. (1990) Smart Homes Wave of the '90s. The Washington Post. https://www.washingtonpost.com/archive/realestate/1990/11/03/smart-homes-wave -of-the-90s/5d69abfe-b115-4edb-92da-5af81699d05f/?utm_term=.6eba30f49602

[34] Li, N. (2017) Smart Buildings Can Help China Manage Energy Use. Global Times. http://www.globaltimes.cn/content/1071983.shtml

[35] Advanced Control Corporation (2013) What Is Intelligent Building Management System?

http://advancedcontrolcorp.com/blog/2013/03/intelligent-building-management-sy stems-in-miami/what-is-intelligent-building-management-system

[36] Energy Saving Trust (2015) Smart Meters and Controls. https://www.energysavingtrust.org.uk/home-energy-efficiency/smart-meters

[37] Ghaffarianhoseini, A., Berardi, U., Al Waer, H., Chang, S., Halawa, E., Ghaffarianhoseini, A. and Clements-Croome, D. (2016) What Is an Intelligent Building? Analysis of Recent Interpretations from an International Perspective. Architectural Science Review, 59, 338-357. https://doi.org/10.1080/00038628.2015.1079164 